\title{
Twins Living Apart: Behavioral Insights/Twin Study Reviews: Managing Monochorionic-Diamniotic Twin Pregnancies; Paternity Testing in Multiple Pregnancies; Twin Research on Resilience; Trisomies in Twin Pregnancies/Human Interest: Reunited Brazilian Twins; Website for Twins with Disabled Co-Twins; Twins Separated in Secret of the Nile Series; Mengele: Unmasking the Angel of Death; Twins Helping Others
}

\author{
Nancy L. Segal \\ Department of Psychology, California State University, Fullerton, CA, USA
}

\begin{abstract}
A brief review of research findings regarding twins living apart is presented. This review is followed by a look into the lives of a pair of monozygotic male twins who have lived in different continents for many years, but who stay closely connected. The reasons behind their decision and its impact on their behavioral resemblance and social relationship quality are examined. The next section summarizes recent studies that address the management of monochorionic-diamniotic twin pregnancies, paternity testing in multiple pregnancies, trisomies in twin pregnancies and the roots of resilience. The final portion of this article presents human-interest stories involving reunited Brazilian twins, a new resource for twins with disabled co-twins, twins separated in the Secret of the Nile television series, a new book about Dr Josef Mengele and his horrific twin experiments conducted at the Auschwitz-Birkenau concentration camp, and a pair of twins dedicated to helping others.
\end{abstract}

\section{Twins Living Apart: Behavioral Insights}

Most twins grow up together but begin to live apart as they attend college, marry, raise families and pursue careers. The decision to live apart is based on many factors, including but not limited to, the educational and occupational interests and opportunities of twins and/or their partners. The quality of the twin relationship can also play a significant role, as evidenced by monozygotic (MZ) twins who marry MZ twins and choose to live next door to one another (Segal, 2005).

The pairs of MZ and dizygotic (DZ) twins who live apart allow researchers to compare their behavioral similarity and relationship quality with $\mathrm{MZ}$ and $\mathrm{DZ}$ twins who live together or in very close proximity. Findings from such studies provide insights into the extent to which a shared environment affects resemblance and relatedness. An early twin study reported that MZ twins who had lived apart for 5 years were more alike in psychosomatic

\section{Author for correspondence: Nancy L. Segal. Email: nsegal@fullerton.edu}

Cite this article: Segal NL. (2020) Twins Living Apart: Behavioral Insights/Twin Study Reviews: Managing Monochorionic-Diamniotic Twin Pregnancies; Paternity Testing in Multiple Pregnancies; Twin Research on Resilience; Trisomies in Twin Pregnancies/ Human Interest: Reunited Brazilian Twins; Website for Twins with Disabled Co-Twins; Twins Separated in Secret of the Nile Series; Mengele: Unmasking the Angel of Death; Twins Helping Others. Twin Research and Human Genetics 23: 300-305, https:// doi.org/10.1017/thg.2020.71 complaints than MZ twins who had always lived together. However, this result was reversed in the case of extraversion (Wilde, 1964). A subsequent study by Claridge et al. (1974) reported greater resemblance in extraversion and divergent thinking among MZ twins who had lived apart for 5 years, relative to those who had always lived together. Consistent with the finding on extraversion, Shields (1962) reported that MZ twins reared apart (MZA) were more alike in both extraversion and neuroticism than MZ twins reared together (MZT). This pattern of findings is not immediately intuitive; however, the investigators proposed that twins reared apart or living apart could more freely express their genetically based traits than twins living together because they were not immediately part of a twin relationship in which social differentiation was inevitable.

These questions were revived in a 1988-1990 debate that played out in the behavioral genetic literature. Richard J. Rose and colleagues published a Finnish study showing that greater contact between twins led to greater similarity in neuroticism (Rose et al., 1988). This conclusion was challenged by Rose's former mentor, David T. Lykken, and colleagues, who asserted that twins who are more alike tend to seek each other's company more often than twins who are less alike (Lykken et al., 1990). A finding related to this debate is that contact frequency was generally unrelated to the behavioral resemblance of MZA twins who participated in the Minnesota Study of Twins Reared Apart (Segal, 2012). 
(a)

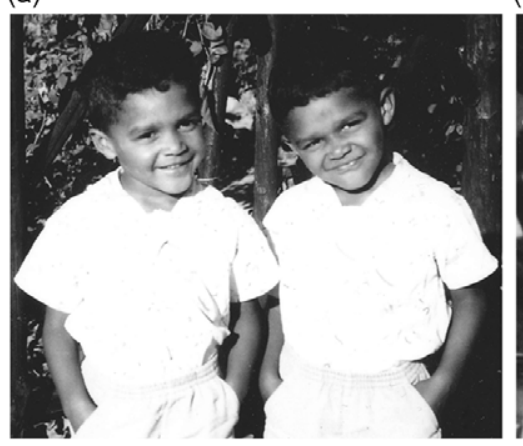

(b)

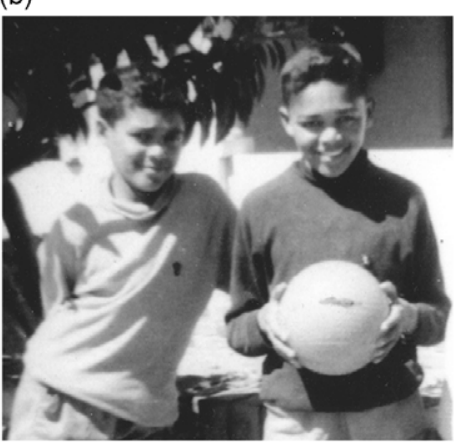

(c)

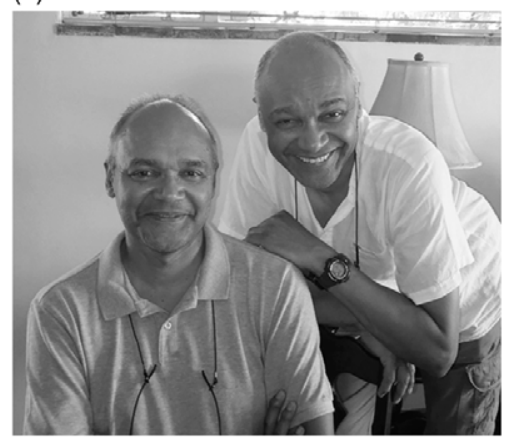

Fig. 1. (a) Twins Michael (L) and Robert Gentle (R) at the age of 5 or 6 years; (b) Michael (L) and Robert (R) at the age of 9 or 10 years; (c) Robert (L) and Michael (R) as adults. Courtesy of Robert and Michael Gentle.

The findings cited above regarding twins living apart versus twins living together have not been replicated by recent twin research, possibly due to different protocols and/or various unknown factors (see also Segal, 2012). However, in my experience interacting with $\mathrm{MZ}$ twins on a personal level, cotwins often appear to be more alike in extraversion and possibly assertiveness than when they are together (Segal \& Montoya, 2018).

The social relationship of twins living apart is also of interest. Based on reasoning by Lykken et al. (1990), we might expect that MZ twins living far apart would be less alike than those living close by. However, as I indicated above, twins' place of residence is complex and may differ as a function of twin type. Interestingly, a study of adult twins found that higher attachment security and relationship satisfaction of $\mathrm{DZ}$ twins, but not MZ twins, was associated with their in-person contact frequency (Neyer, 2002). As such, some MZ twins maintain close social ties despite infrequent visits.

An opportunity arose to closely examine the life histories, life choices and social relationship of a pair of 62-year-old MZ male twins who have lived in different continents for 36 years - over half their lives. The twins, Michael and Robert Gentle, came to my attention from journalist Erika Hayasaki. Hayasaki had authored an article on twins for The Atlantic, for which I was interviewed (Hayasaki, 2018). Michael described their interesting story to Hayasaki and she referred them to me. In the weeks that followed, both twins provided insightful information about their twin resemblance and twin relations. They began living apart at a relatively young age, an event that came about naturally because of each twins' particular interests and talents.

The Gentle twins, 62 years old, are originally from South Africa, where they described themselves as of mixed Black, White and Indian ethnicity. Their grandparents were also of mixed background, representing Scottish, Black African, Irish, Indian, German and local Cape ancestry. Both twins are right-handed and have no other brothers or sisters. They appear to be MZ, based on my inspection of an adult photograph; more importantly, their monozygosity is reflected by results from a standard physical resemblance questionnaire (Nichols \& Bilbro, 1966). The twins' heights are identical at 70.5 in or $1.79 \mathrm{~m}$ each, while they differ slightly in weight - Robert weighs 4.4 pounds or $2 \mathrm{~kg}$ more than Michael. Their hair color and eye color are the same. On the questionnaire, the twins were diagnosed as $\mathrm{MZ}$ at level 2, rather than at level 1 , because neither twin indicated that they were 'frequently mistaken' by parents when young or recently, or were 'frequently mistaken by close friends'. These items may be questionable in the case of Michael and Robert because they are not often together. However, some incidents from their childhood and beyond are telling.

Michael noted that up until the age of 10 years, he and Robert were confused for one another at school where uniform dress was required. However, mistaken identity occurred less often when they began dressing differently. On one occasion, when they were living apart, Robert visited Michael in Europe and Michael asked him to enter a colleague's office and pretend to be him. Colleagues were fooled but sensed that something was not quite right. The twins' slight differences are more apparent when they are together, which is typical of most MZ twins. Interestingly, the twins' relatives have frequently confused them, probably because they have seen them less often than their parents, who are known to be sensitive to twins' subtle differences. Relatives often tired of asking which twin was which before deciding to call each one 'Michael-Robert'.

In the remainder of this article, I will briefly review the twins' life histories, both together and apart, then place the findings into a larger research context. A photograph of the twins appears in Figure 1.

Robert now lives in Johannesburg, South Africa, while Michael lives near Lisbon, Portugal. However, from childhood to young adulthood, the twins lived together and pursued the same studies, sports and other activities. Through their teens both played football, tennis and basketball. One twin described their relationship as 'closer than best friends', the other 'as close as best friends' during their growing up years. The twins' higher educational programs also started out in tandem - both studied mechanical engineering at the university level in Zambia, then studied aeronautical engineering and information technology (IT) in France. It was soon after entering the workplace that their diverging interests took them in different directions. In 1984, while still in France, both twins were working in IT when Robert decided that becoming an author was what he really wanted to do. According to his twin brother Michael, 'the decision really surprised me'.

Robert returned to South Africa to write a novel, living at home with his parents because he lacked financial independence at that time. As Michael observed, Robert turned out to be a very skillful writer, eventually entering the fields of journalism and communications. On his profile, Robert defines himself as a 'global trainer' and introduces himself by stating 'Robert Gentle's my name and writing's my game'. He has worked as a financial journalist in Johannesburg, London and Paris and has done public relations and media relations work for large companies. Robert has also 
trained managers and executives. $\mathrm{He}$ is currently based in Johannesburg but serves countries in Europe, the Middle East and Asia. Robert is divorced and does not have children.

After earning his degree, Michael remained in Paris, working in the IT field, but he has since lived in Canada, Switzerland and now Portugal. The designation on his website profile is 'multicultural communicator'. Michael's areas of expertise span IT, project management, sales and marketing. He has worked for global companies such as Apple, WorldCom, The Bank of Tokyo and Nestle. He is now retired but continues to teach English and work in English language translation and communication. Like his twin brother, Michael is divorced, but he has three children, two sons and a daughter. Twin studies show that divorce has a partial heritable component, so it may not be surprising that the twins match in this respect (D'Onofrio et al., 2007).

Even though writing is Robert's specialization, both twins have written well-received books. Michael Gentle is the author of IT Success! Toward a New Model for Information Technology (2007), The CRM Project Management Handbook (2002) and An Introduction to IT Project Financials (2010). He has also written an extensive list of articles, in both English and French. Some of his work can be accessed at htpps://medium.com/the-balanceof-privacy. Robert Gentle has authored the best-selling book Read This! Business Writing that Works (2002a), which is used by companies around the world. He is also the author of Consultant - Market Yourself: Raise Your Profile and Attract New Business (2002b), and Conversations with Bob: Why Everything's Going to be Okay (2013). Many of his articles can be accessed at https://www.bizcommunity.com/Profile/RobertGentle.

The twins' similarities extend to many aspects of their behavior and lifestyle, including their sense of humor, physical activities, reading, writing and languages. They send each other links to humorous articles and take pleasure in each other's attempts at telling jokes. Without consulting one another, both twins have been eating healthy foods, limiting their alcohol intake and engaging in physical activity in the morning and in the evening. Both Michael and Robert loved to read as children and still do. They often suggest books to one another, and their suggestions are taken seriously. Michael suggested that the twins' shared love of reading comes from watching their parents who were both teachers. I would add that their parents provided an environment for them that was compatible with their genetically based proclivities. Genes and environments cannot be disentangled in intact biological families, since parents transmit both genes and environments to their children.

Both twins have mastered several languages. They grew up speaking both English and Afrikaans, but excelled in high school French, explaining their decision to study in France. Michael also speaks Spanish, learned Swedish for a year and has now mastered Portuguese to a large degree. Robert has added German to his linguistic repertoire. Part of Michael's language learning has come from listening to music, and part of Robert's has come from watching German movies and documentaries on YouTube. Languages come easily to them, but they also share the motivation and dedication to acquire them. Interestingly, both twins avoid the news media, believing that it can become all-consuming. However, on weekends, Michael reads The Economist, The Financial Times and Le Monde, whereas Robert browses books and magazines at local bookstores; that practice may be curtailed in light of the COVID-19 pandemic. In fact, Robert was unaware of the coronavirus when Michael mentioned it to him in January.
Michael and Robert have some self-reported differences that are worth noting. Michael's mind is 'too hyperactive' for meditation, an activity with which Robert has been involved since his twenties. And, unlike Robert, Michael experiences difficulty sleeping through the night. Robert is somewhat more relaxed, but perhaps that is because of his meditation. The twins' political views both coincide and contrast. Both have always leaned politically to the right, but in conversations with each other, they are aware that Michael's views reflect exposure to his European culture and Robert's views reflect exposure to his Anglo-American culture. (Robert spent time in the UK and, according to Michael, South Africa strongly reflects Anglo-American views.) They accept each other's opinions with respect and congeniality. However, given Robert's interest in German culture, Michael sees some evidence that his brother's views are tilting in a European direction.

The decision that put the twins over 5000 miles, or $8700 \mathrm{~km}$, apart was an easy one for Michael and Robert. They realized that geographical proximity was not required in order for them to maintain their customary closeness. They visit each other once or twice each year and engage in weekly video calls that last about an hour. These twins are a good example of what Neyer (2002) reported, namely that that the quality of $\mathrm{MZ}$ twin relationships does not depend on their frequency of in-person contact. Of course, Michael and Robert rely largely on video communication to stay in touch, a means that was not available to the twins in Neyer's study. Most importantly, the Gentle twins feel no regrets over the fact that their careers have placed them in different continents. They enjoy their twinship completely without sacrificing their professional lives. The closeness ratings they provided for their childhood and teenage years are unchanged.

Looking closely at the life choices of MZ twins, especially twins living apart, requires careful consideration of what defines a difference. Michael and Robert work in different fields, but they have both brought similar skills - writing ability and language facility - to their chosen professions. Their political attitudes are generally similar, although some of their views have been shaped by the culture in which they have lived and worked. Twin researchers have seen this effect before, especially in the striking case of reared-apart twins, Jack and Oskar. Born in 1933 and separated at the age of 6 months, Jack was raised Jewish in Trinidad by his father, while Oskar was raised Catholic by his mother in Germany. Both twins coped similarly with their unusual situations, by becoming very supportive of their respective nation. However, Jack became very pro-British and Oskar became very pro-German (Segal, 2005).

Particularly striking are Michael and Robert's matched, independently made decisions to pursue healthy eating and activity habits. This illustrates the finding that shared environments do not contribute a great deal to behavioral resemblance among family members living together. As an example, the behavioral resemblance of adoptive relatives living together does not approach that of $\mathrm{MZ}$ twins reared apart. Instead, the behavioral similarities of family members are mostly due to their shared genes, guiding them toward similar people, places and events in their respective environments. I suspect that that is the case with Michael and Robert. Furthermore, I have always believed that MZ twins' similarities are most impressive when twins do not intentionally try to mimic one another. I recall being a judge in a twin similarity contest, asked to choose the most identical MZ twin pair from among four sets. The members of my panel and I chose a pair that did not try to be alike but were very much alike, regardless. They remind me of Michael and Robert. 
I am grateful to Michael and Robert Gentle for sharing their twinship and their life stories with me. Their information and insights make twin data meaningful and lively. Their website profiles can be viewed at: Robert, https://www.robertgentle.com/ about; and Michael, https://www.english-in-setubal.pt/about.

\section{Twin Study Reviews}

\section{Managing Monochorionic-Diamniotic Twin Pregnancies}

Monochorionic-diamniotic (MCDA) twins occur in approximately $1 / 300$ pregnancies. A review of the literature by Lewi (2020) addresses the nature, causes, diagnosis, assessment, delivery and complications of this type of twinning. The review was written with the specific aim of deciding how best to inform prospective parents of MCDA twins. Key facts that are known, as well as new material included in the report, are summarized in helpful charts. In brief: (1) MCDA twins are at risk from the hazards of shared prenatal circulation; and (2) in $15 \%$ of the MCDA pairs there is an imbalance in blood exchange, resulting in twin-to-twin transfusion (TTTS) and twin anemia polycythemia sequence (TAPS). TTTS is a condition in which monochorionic twins share a single placenta and the blood vessels that provide oxygen and nutrition. TAPS is a form of TTTS in which the blood supply between co-twins is uneven. The recipient twin is at risk for successively increasing blood count or polycythemia, and the donor twin is at risk for progressive blood loss or anemia (Johns Hopkins Medicine, 2020a, 2020b).

There is reassuring news for parents that will help them make informed decisions together with their physicians. MCDA twins have the most favorable outcomes if born between 36 and 37 weeks of gestation. There are prenatal surgical options for managing TTTS and TAPS. Approximately $80 \%$ of MCDA twin pregnancies are successful. The health and wellbeing of MCDA twins should be followed until school age to determine whether there are neurodevelopmental delays. A multidisciplinary medical team, consisting of obstetricians, a perinatal psychologist, a physiotherapist and a dietician, as needed, will help to obtain favorable results.

\section{Paternity Testing in Multiple Pregnancies}

Noninvasive prenatal paternity testing has been used in cases involving sexual assault, alimony and inheritance. However, more invasive measures such as chorionic villus sampling pose some risk of miscarriage. Researchers in China have performed a procedure in twin pregnancies using parental DNA and maternal plasma cellfree DNA (Xie et al., 2020). The method combines single-nucleotide polymorphisms and massively parallel sequencing technology, also known as next-generation sequencing (NGS). NGS refers to techniques in which millions of nucleotide sequences are identified simultaneously (Franklin et al., 2020).

Blood samples were obtained from 15 women whose twin pregnancies had advanced to between 9 and 18 weeks. Each sample was assessed against the alleged father and 90 unrelated males. The correct biological father was correctly identified in each case, allowing exclusion of the other 90 participants. This technique has implications for legal cases and related situations involving heteropaternal twinning, in which nonidentical twins are fathered by different males (see Segal et al., 2019).

\section{Trisomies in Twin Pregnancies}

A prospective study of the efficacy of noninvasive prenatal testing (NIPT) of twin pregnancies for trisomy 21 (Down syndrome), trisomy 18 (Edwards' syndrome) and trisomy 13 (Patau syndrome) is of interest. The work was conducted by He et al. (2020), who represent a number of universities and hospitals in China. The researchers asserted that prenatal screening of multiple pregnancies is becoming increasingly important because such conceptions are rising due to advances in reproductive technology. The study sample initially included 146 pregnancies identified at the First Affiliated Hospital of Sun Yat-sen University (111) and Kanghua Hospital (35); however, the results were based on 141 cases. One occurrence of trisomy 21 was confirmed, with the remaining 140 cases proving negative. A meta-analysis was then conducted by combining the present dataset with data from 22 other studies. The use of NIPT for identifying trisomy 21 was excellent, with a pooled sensitivity of .99 , similar to that obtained in nontwin pregnancies. However, the authors cautioned that publication bias in the case of trisomy 18 and the small number of occurrences in the case of trisomy 13 limited the accurate assessment.

\section{Twin Research on Resilience}

Resilience is a quality that many people covet but not everyone can display to the same degree when confronted with stress or trauma. The roots of resilience were examined in a self-report study involving 2056 female twins (Sawyers et al., 2020). Related research aims involved assessing the genetic and environmental overlap between self-reported resilience and outcome-based resilience, and understanding the commonality between the two resilience measures and major depressive disorder. In this study, resilience was defined as the absence of psychiatric symptoms following stressful life events. Participants came from the first wave of the Virginia Adult Twin Studies of Psychiatric and Substance Use Disorders.

Protocols included a perceived resilience questionnaire for the self-report portion of the study, an abbreviated version of the Symptom Checklist-90 to examine distress symptoms over the past month, and a personal clinical interview - a modified version of the Structured Clinical Interview for DSM-III-R Axis - administered by trained individuals who were unaware of the twins' zygosity. There were several main findings. Perceived resilience showed a modest heritability estimate of $11 \%$. Only a slight environmental overlap, estimated at $3 \%$, was found between the two resilience measures. Last, genetic factors influencing self-perceived resilience explained $3 \%$ of the heritability of major depressive disorder, while $31 \%$ of its heritability was linked to factors associated with the absence of psychiatric symptoms following life stress, labeled discrepancy-based psychiatric resilience.

\section{Human Interest \\ Reunited Brazilian Twins}

Brazilian twins, Tomaz Maranhão, from Fortaleza, and Gabriel Ferreira, from Uberaba, met for the first time at the age of 23 years (TV Verdes Mares and TV Integração, 2020). The twins appear to be identical, based on inspection of their photographs. They were separated at birth because their mother could not afford to raise two children. They are originally from outside Fortaleza where Tomaz was given to an adoptive family at the age of 15 days. His twin brother Gabriel was given to an adoptive family in Uberaba when he was 7 months old. Tomaz's family knew he was a twin and revealed that information to him when he was a young child. 
Tomaz and Garbriel share a passion for photography, a vocation that was actually responsible for bringing them together. When Tomaz turned 16, his biological mother gave him a faded photograph showing his twin brother celebrating his first birthday miles away. Tomaz tried hard to find his twin, but his search was unsuccessful. Gabriel always knew that he had a twin, but he was unaware that his brother was searching for him. One day, Tomaz noticed that the photograph of his brother included his biological mother's name. He continued searching through social media until he found a picture of an individual with the right name - and the person looked exactly like him. His success ultimately allowed the brothers to be in touch by telephone and the internet. They finally met when Tomaz's wife crafted a surprise plan to bring the twins together. According to Gabriel, 'Everyone has a material dream, a dream of reaching goals, but this dream that I had of meeting my twin brother is much more than that'. Tomaz replied, 'I found what I needed all my life, which was to have him, to be able to know, I feel completely fulfilled, at the age of twenty-three'. Dr Emma Otta, my Brazilian colleague at the University of São Paulo, and I wish to study the twins - and they have agreed.

\section{Website for Twins with Disabled Co-Twins}

Harvard University alumni Nathan Grant has launched a website for twins and siblings with disabled brothers and sisters (Siliezar, 2020). The idea for the website grew out of Nathan's personal experience - the website is called Siblings on a Mission. When Nathan was 3 years old, his twin brother Nik was diagnosed with Hunter syndrome. This condition, which occurs almost exclusively among males, is marked by respiratory problems, stunted growth, developmental disabilities and a shortened life span. It is also known as Mucopolysaccharidosis type II (National Institute of Health, 2020).

Physicians predicted that Nik would live until about the age of 10 years, but the brothers are now 22 years of age. When Nathan studied at Harvard, he majored in molecular and cell biology to better understand and help his twin brother and others with Hunter syndrome. Hunter syndrome is an X-linked recessive disease, explaining why one DZ male twin (Nik) was affected and his twin brother (Nathan) was not (Takeda Pharmaceutical Company Limited, 2020). Specifically, their mother carried the detrimental gene on one of her two X chromosomes and transmitted different $\mathrm{X}$ chromosomes to her twin sons. This also explains why males are more highly affected than females. However, a case of female twins discordant for the condition, due to differential X-inactivation, has been reported (Winchester et al., 1992).

The website enables individuals to share their stories but also organizes helpful informational events. In July 2017, the group organized a symposium with the Cincinnati Children's Hospital that attracted over 100 members and medical researchers. The organization now includes nearly 500 members from 25 states and 15 nations. Additional information can be found on their website at http://www.siblingswithamission.org/.

\section{Twins Separated in Grand Hotel: Secret of the Nile Series}

The coronavirus pandemic has forced many people to work away from their laboratories and offices. It has also expanded their evening and weekend hours at home. I had the pleasure of watching a television series titled Grand Hotel, which will interest readers of Twin Research and Human Genetics because several of the later episodes involve identical twin infants, separated at birth by virtue of an incredible and alarming scheme. As the plot developed, I was pleased to have predicted that one of the lead characters, a pregnant maid, was about to deliver twins. The series can be watch on Netflix (Egyptian TV, 2016).

\section{Mengele: Unmasking the Angel of Death}

A June issue of the New Yorker Magazine has reviewed a new book about the life of Dr Josef Mengele (Gopnik, 2020). Mengele was the infamous Auschwitz physician who conducted horrific medical experiments on twins and individuals with various genetic anomalies. The author of Mengele: Unmasking the Angel of Death, David G. Marwell, is the former Director of the Museum of Jewish Heritage in New York City (Marwell, 2020). Marwell is also a former member of the Office of Special Investigations at the US Department of Justice, where he was assigned to the international effort to find Mengele and bring him to justice. I have read the book and can attest to the fact that it is an insightful new look at this tragic episode in human history, with critical implications for judicial responsibility, public accountability and twin research.

My interests in this area date back to 1985 . That year, I attended the 40th anniversary reunion of the Mengele twins who survived the Holocaust. Over the years, I have attended several related gatherings and conferences and have written several papers and chapters about the Holocaust twins' lives and the medical experiments (Segal, 1985, 1992), one in Twin Research and Human Genetics (Segal, 2013).

\section{Twins Helping Others}

Identical twins, Renee and Rhea Mendonca, of Long Island, New York, have launched a campaign against drugs, smoking and vaping (Summer of Service, 2020). They have called their effort 'Wings of Hope'. They were motivated to act following the death of their grandfather who had been a chain-smoker since the age of 14 years and had developed pulmonary fibrosis. The Mendonca twins give lectures at schools to acquaint students and others with the health hazards linked to smoking and substance abuse. They have made considerable progress - $25 \%$ of the teachers and $40 \%$ of the staff have decided to stop smoking, and $50 \%$ of the students have pledged to give up smoking and drugs. It is estimated that Wings of Hope has helped 7000 young people confront their addictions.

\section{References}

Claridge, G., Canter, S., \& Hume, W. I. (1974). Personality differences and biological variations: A study of twins. Pergamon Press.

D’Onofrio, B. M., Turkheimer, E., Emery, R. E., Harden, K. P., Slutske, W. S., Heath, A. C., .. . Martin, N. G. (2007). A genetically informed study of the intergenerational transmission of marital instability. Journal of Marriage and Family, 69, 793-809.

Egyptian TV. (2016). Secret of the Nile. https://www.netflix.com/title/802 15154

Franklin, W. A., Aisner, D. L., Davies, K. D., Crooks, K., Post, M. D., Kleinschmidt-DeMasters, B. K., .. Varella-Garcia, M. (2020). Pathology, biomarkers, and molecular diagnostics. In J. E. Niederhuber, J. O. Armitage, J. H. Doroshow, M. B. Kastan \& J. E. Tepper (Eds.), Abeloffs clinical oncology (6th ed., pp. 225-253). Elsevier.

Gopnik, A. (2020, June 22). Measuring man: Josef Mengele's Malignant 'Science'. New Yorker Magazine, pp. 77-81.

Gentle, M. (2002). The CRM project management handbook: Building realistic expectations and managing risk. Kogan Page.

Gentle, M. (2007). Its success! Toward a new model for information technology. John Wiley \& Sons. 
Gentle, M. (2010). An introduction to IT project financials: Budgeting cost management and chargebacks. Lulu Press.

Gentle, R. (2002a). Read this! Business writing that works. Pearson Education.

Gentle, R. (2002b). Consultant market yourself: Raise your profile and attract new business. Kogan Page.

Gentle, R. (2013). Conversations with Bob: Why everything's going to be okay. CreateSpace Independent Publishing Platform.

Hayasaki, E. (2018, May 15). Identical twins hint at how environments change gene expression. The Atlantic. https://www.theatlantic.com/science/archive/ 2018/05/twin-epigenetics/560189/

He, Y., Wang, Y., Li, Z., Chen, H., Deng, J., Huang, H., ... Chen, P. (2020). Clinical performance of non-invasive prenatal testing for trisomies 21, 18 and 13 in twin pregnancies: A cohort study and a systematic meta-analysis. Acta Obstetricia et Gynecologica Scandinavica, 99, 731-743.

Johns Hopkins Medicine. (2020a). Twin-to-twin transfusion syndrome (TTTS). https://www.hopkinsmedicine.org/health/conditions-and-diseases/ twintotwin-transfusion-syndrome-ttts

Johns Hopkins Medicine. (2020b). Twin anemia polycythemic sequence (TAPS). https://www.hopkinsmedicine.org/health/conditions-and-diseases/ twin-anemia-polycythemia-sequence-taps

Lewi, L. (2020). Monochorionic diamniotic twins: What do I tell the prospective parents? Prenatal Diagnosis, 40, 766-775.

Lykken, D. T., McGue, M., Bouchard, T. J., \& Tellegen, A. (1990). Does contact lead to similarity or similarity to contact? Behavior Genetics, 20, 547-561.

Marwell, D. G. (2020). Mengele: Unmasking the angel of death. W.W. Norton \& Co.

Museum of Jewish Heritage. (2020). Mengele: Unmasking the angel of death, with David G. Marwell. https://mjhnyc.org/events/mengele-unmasking-theangel-of-death-with-author-david-g-marwell/

National Institute of Health. (2020). Mucopolysaccharidosis type II. https:// ghr.nlm.nih.gov/condition/mucopolysaccharidosis-type-ii

Neyer, F. J. (2002). Twin relationships in old age: A developmental perspective. Journal of Personality and Social Relationships, 19, 155-177.

Nichols, R. C., \& Bilbro, W. C. (1966). The diagnosis of twin zygosity. Acta Geneticae et Statistica Medicae, 16, 265-275.

Rose, R. J., Koskenvuo, M., Kaprio, J., Sarna, S., \& Langinvainio, H. (1988). Shared genes, shared experiences, and similarity of personality: Data from 14,288 adult Finnish co-twins. Journal of Personality and Social Psychology, 54, 161-171.

Sawyers, C., Kurtz, E. D., Sheerin, C., Maes, H. H., Kendler, K. S., \& Amstadter, A. B. (2020). A behavioral genetic investigation of conceptualizations of resilience in a female twin sample. Depression and Anxiety, 37, 532-539.
Segal, N. L. (1985). Holocaust twins: Their special bond. Psychology Today, 19, 52-58.

Segal, N. L. (1992). Twin research at Auschwitz-Birkenau: Implications for the use of Nazi data today. In A. Caplan (Ed.), When medicine went mad: Bioethics and the Holocaust (pp. 281-299). Humana Press.

Segal, N. L. (2005). Indivisible by two: Lives of extraordinary twins. Harvard University Press.

Segal, N. L. (2012). Born together-reared apart: The landmark Minnesota twin study. Harvard University Press.

Segal, N. L. (2013). The twin children of Auschwitz-Birkenau: Conference on Nazi medicine. Twin Research and Human Genetics, 16, 751-757.

Segal, N. L., Craig, J. M., \& Umstad, M. P. (2019). Challenge to the assumed rarity of heteropaternal superfecundation: Findings from a case report. Australian Journal of Forensic Sciences. https://doi.org/10.1080/00450618. 2019.1616821

Segal, N. L., \& Montoya, Y. S. (2018). Accidental brothers: The story of twins exchanged at birth and the power of nature and nurture. St. Martin's Press.

Shields, J. (1962). Monozygotic twins: Brought up apart and together. Oxford University Press.

Siliezar, J. (2020, June 4). Sibling on a Mission. Harvard University Gazette. https://news.harvard.edu/gazette/story/2020/06/grad-advocates-for-peoplewith-disabilities-and-their-families/2020.

Summer of Service. (2020). Everyday Young Hero - Renee and Rhea Mendonca. $\mathrm{https} / / /$ leadasap.ysa.org/share_story/everyday-young-hero-renee-mendonca/

Takeda Pharmaceutical Company Limited. (2020). Genetics of Hunter syndrome. https://www.hunterpatients.com/what-is-hunter-syndrome/genetics-ofhunter-syndrome

TV Verdes Mares and TV Integração. (2020, June 28). Gêmeos Separados Após Aascimento se Reencontram e Têm o Primeiro Aniversário Juntos Aos 23 Anos [Twins separated after birth meet again and have their first birthday together at 23]. https:/g1.globo.com/ce/ceara/noticia/2020/06/28/ gemeos-separados-apos-nascimento-se-reencontram-e-tem-o-primeiroaniversario-juntos-aos-23-anos.ghtml

Wilde, G. J. S. (1964). Inheritance of personality traits: An investigation into the hereditary determination of neurotic instability, extraversion, and other personality traits by means of a questionnaire administered to twins. Acta Psychologica, 22, 37-51.

Winchester, B., Young, E., Geddes, S., Genet, S., Hurst, J., Middelton-Price, H., ... Malcolm, S. (1992). Female twin with Hunter disease due to nonrandom inactivation of the X-chromosome: A consequence of twinning. American Journal of Medical Genetics, 44, 834-838.

Xie, Y., Qu, N., Lin, S., Jiang, H., Zhang, Y., Zhang, X., . . Ou, X. (2020). Noninvasive prenatal paternity testing by maternal plasma DNA sequencing in twin pregnancies. Electrophoresis, 41, 1095-1102. 